\title{
THE DEVELOPMENT OF ELECTROMOBILITY IN POLAND
}

\author{
Wojciech Drożdż
}

\begin{abstract}
The article discusses the development of electromobility in Poland. The first part of the article highlights the significance of electromobility for the national transport and energy policy. The second part of the article describes issues related to the development of charging infrastructure. The article also presents plans for the expansion of charging stations and barriers related to it. The article discusses market segments in which electric cars are actually used. Finally, the article describes stages of electromobility development in Poland and indicates its benefits for Poland. Being a new rapidly developing industry, electromobility can be an opportunity for Polish businesses and a stimulating factor for the entire national economy. The article is concluded with a summary.
\end{abstract}

Keywords: electromobility, electric vehicles, development policy

JEL Classification: E69, F43, O30, P18

\section{Author(s):}

Wojciech Drożdż

University of Szczecin, 31, Al. Papieża Jana Pawła II, Szczecin, Poland, 70-451

E-mail:wojciech.drozdz@enea.pl

https://orcid.org/0000-0001-5915-546X

Citation: Drożdż, W. (2019). The development of electromobility in Poland. Virtual Economics, 2(2), 6169. https://doi.org/10.34021/ve.2019.02.02(4) 


\section{Introduction}

The influence of the European energy market on the Polish energy sector has been increasingly important, both in terms of regulations and environmental issues. While trying to meet new requirements, Poland has been trying to deal with the new idea for the transport and energy market. In recent years, Poland has noted a dynamic growth of the sectors which use advanced technologies. Those solutions include electromobility which, as late as 2018 , marked its presence on Polish roads.

On $22^{\text {nd }}$ February 2018, the Electromobility and Alternative Fuel Act of $11^{\text {th }}$ January 2018 became effective (Electromobility and Alternative Fuel Act of 11th January 2018, JoL item 317, 2018). The new law defined a framework for modernisation and adjustment of infrastructure to handle electric cars. Poland, as an EU member state, would like to catch up with other countries where such solutions have already been implemented. A major issue supporting the transport sector is a continuous development of technical and formal framework which, once combined with regulations and economic solutions, may create a modern system of new modes of transport. Most importantly, such solutions have been implemented in line with the idea of ecological transport. Poland should play an active role in the global process of promoting electromobility. One of the arguments for such an involvement is that Poland enjoys a major potential of its automotive industry, energy as well as research and development, and laboratory and maintenance services.

\section{The role of electromobility in the Polish sectors of transport and energy}

The broadly understood market of electromobility products and services has been rapidly developing locally and globally (Benveniste et al., 2018; De Lara and Marx, 2018; May, 2018). The promotion of electromobility may turn to be an excellent solution for the Polish energy sector which one day may translate into economic improvements and specific social benefits. It can also have a positive influence on the life quality of people living in major cities where specific solutions will be applied. The Electromobility Development Plan in Poland (2017) puts much attention to the operation of the National Grid. It is related to the potential increase in sales of electricity. Poland has very scarce resources of oil needed to produce fuel for cars. However, the Poland's geographic location supports generation of energy from sources available, including renewable energy sources, which translates into the independence of the entire system.

Plans to have one million electric cars on Polish roads by 2025 create prospects for integrating various modes of transport and the power supply system, and stimulating the development of the Polish industry (Electromobility Development Plan in Poland. Energy for the Future, 2017). Globally, the annual sales of electric vehicles is at the level of 500 thousand. "The fact that the Polish government has adopted [...] the Electromobility Development Plan in Poland (2017), which is expected to create condition for Polish pioneers in electric transport fits into the trend" (Drożdż, 2018). The Plan highlights the need to designate funding for the development of charging infrastructure and the grid. The tasks specified in the Plan define a general strategy 
for the central government, local governments, as well as distribution system operators (DSO). The objective adopted in the plan can be successfully achieved through the cooperation and mutual understanding of all parties involved. The Plan defines the best possible distribution of infrastructure, i.e. critical locations where the functionality of an electric vehicle is the lowest in the case of infrastructure shortage (Electromobility Development Plan in Poland. Energy for the Future, 2017). In practical terms, it means that charging stations should be developed in all major cities and along trans-European transport corridors passing through Poland. At the same time, tools for further development of electric vehicles should be precisely defined, since their number on Polish roads will unavoidably grow. New regulations on electromobility is a challenge for DSOs. In order to ensure uninterrupted and efficient power supply, it is necessary to increase spending on the development and modernisation of the grid. DSOs can expect a pressure to increase spending on connecting electric vehicle charging stations (Electromobility Development Plan in Poland. Energy for the Future, 2017). The increased demand for electricity when electric vehicles are charged emphasises the need to develop energy storages to meet the demand and, in general, to stabilise the grid. In Poland, several projects are already underway to test batteries and finally develop energy storages.

An additional argument for developing electromobility is the care for sustainable development in line with the ecological transport principles, hence reduced emission of dust, gases, and noise, as well as improved comfort of public transport. Several companies in Poland have already started manufacturing electric buses. Solaris Urbino 12 Electric received the title of the Bus of the Year during the industrial fair in Hanover, Germany, in recognition as the best urban bus of 2017 (Onet, 2017). The use of electric engines reduces air pollution. Wider use of zeroemission buses and electric cars in Poland may be an important factor influencing the air quality (Electromobility Development Plan in Poland. Energy for the Future, 2017). Although traffic pollution with PM10 is not a major problem in the scale of the entire country (5.4-7\%), it is worth mentioning that in larger cities, e.g. Warsaw or Silesian conurbation PM10 accounts for $60 \%$ of the total emission (Smoglab, 2018). An advantage of the electric engine for the user of public transport in Poland is the reduced noise level. Thus, the promotion of urban transport can focus on emphasising quiet engines. Reduced street noise in large cities is important while creating areas of public friendly space or 'green cities'. Additionally, a larger use of public transport results in reduced demand for parking space in cities.

\section{Charging infrastructure and electric car market in Poland}

According to estimates of the Ministry of Energy, in Poland, over $300 \mathrm{EV}$ charging stations are already in operation. The distribution of charging stations in Poland is presented in Fig. 1.

The Electromobility Act has created a legal basis for the development of charging and CNG/LNG refuelling infrastructure and defined rules for creating and operating of the alternative fuel market in transport. By the end of 2020, we expect about 6 thousand regular speed charging stations and 400 fast-charging stations, as well as 70 CNG refuelling stations in 32 cities and densely populated areas. The Act assumes that the first stage of developing charging stations should take place in 2018 and 2019, and the infrastructure should develop in 
the same period based on market principles with the support of public funding. If by 2020 the required number of charging stations is not developed in relevant municipalities as specified by the Act, a municipality falling short of the infrastructure will be required to develop a plan to develop the missing charging infrastructure, and the local DSO will be responsible for the building of missing charging stations (Electromobility and Alternative Fuel Act of 11th January 2018, JoL item 317, 2018).

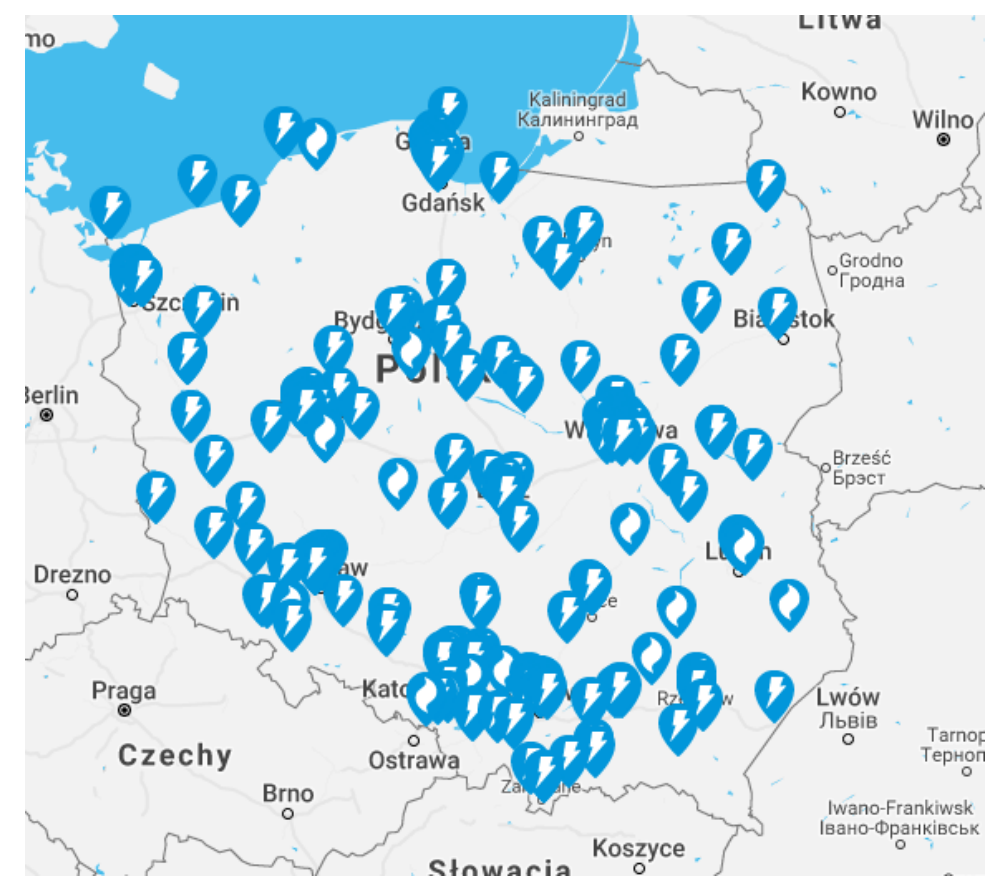

Figure 1. Charging stations in Poland, 31.08.2018

Source: Register of alternative fuel infrastructure (Obserwatorium Rynku Paliw Alternatywnych, 2018)

The development of new charging stations is held back due to financial as well as legal reasons. According to estimates, the establishment of a new slow charging station may cost about PLN 40 thousand, whereas in the case of a fast-charging station the cost increases to PLN 100-190 thousand (Wysokie napiecie, 2018). The access to public stations is free of charge and most often used to promote a specific company or the idea of electromobility itself. The Ministry of Energy declared that, according to their estimates, profitability of a charging station can be reached once the sale reaches $32.85 \mathrm{MWh}$ for a regular station, whereas for a fast-charging one - 452.6 MWh (Polityka insight, 2018). A large margin, however, should be added to those figures, since they are calculated based on the energy price which is no longer used on the market. Nevertheless, in Poland, a growing number of companies are interested in building general access charging stations. By 2020, Green Way Infrastructure Poland intends to establish 200 charging stations, and LIDL plans to develop a general access chargers at their premises in Poland in cooperation with an external partner (www.abb.pl).

In 2017, about 1,224,000 EV/PHEV were sold globally. Due to a significant increase in China, the market grew by $58 \%$ comparing to a previous year. Provided the growth rate is maintained, 
in 2018 we can expect to reach 2,000,000. Then, until the end of December, we will have $5,000,000 \mathrm{EV} / \mathrm{PHEV}$ s in the world (Transport publiczny, 2018). Leading electric vehicle markets include EU and the US as well as the recently rapidly growing Asian market. The Polish automotive market can be considered attractive, since Poland is a major global manufacturer of combustion engines. The market comprises more than ten manufacturers with about $85 \%$ of their production sold abroad (Transport publiczny, 2018). Moreover, Poland has been steadily developing production of components for electric vehicles, as well as electric and electronic equipment. Poland has 700 manufacturers of components, of which over 400 are companies with Polish interest (Transport publiczny, 2018). They manufacture components to all makes of cars. An important piece of information for foreign investors interested in the automotive sector in Poland is that nine out of ten leading global manufacturers have their plants in Poland. Even considering the above, it is not going to be easy to have one million electric vehicles present on Polish roads by 2025 . However, provided we use resources available and show relevant determination to meet the challenge, the goal can be realised to a large extent. Additionally, this creates prospects for the integration of various modes of transport with the power grid. While cooperating with Polish and foreign companies, businesses currently operating on the market can look for new solutions and develop their resource base.

General changes in the urban transport create an opportunity for the development of electromobility. Main activities implemented by Polish cities are designed to increase the share of public transport at the cost of individual cars. Still a large number of citizens living in major cities prefer to use their own cars instead of public transport, including buses and trams. This contributes to congestion in cities, which slows down the traffic during peak hours and sometimes brings the traffic to a halt causing a high concentration of exhaust gas emission. The trend to use individual cars results from suburbanisation, or moving to city outskirts. Usually, such areas have poor transport accessibility and the use of individual cars remains the only alternative. Park \& Ride facilities situated at the entrance to the city might be a solution, since drivers can leave their cars there and continue travelling using public transport. To provide an efficient public transport, the city needs a suitable network of tram and bus lines. Trams do not cause emission, but buses do and we need to find an alternative for combustion engine buses to reduce pollution. There electric buses come into play. Poland is one of the leaders in manufacturing and selling electric buses (portalsamorzadowy.pl). Solaris, as mentioned above, is a well-recognised brand in Europe and in the world. Additionally, the Ebus programme has been launched to support designing and manufacturing of the Polish electric bus. By 2025, the Polish Electric Bus should be ready with $100 \%$ Polish content. The Polish bus market is going to reach the value of PLN 2.5 bn annually (MPiT, 2018). It is also worth mentioning that in 2017 a letter of understanding was signed between the Ministry of Energy, Ministry of Development, National Research and Development Centre, Polish Development Fund, and 41 cities; the latter declared to increase the number of electric buses in their fleet.

Putting an increased pressure on public transport does not make people resign from using their cars. Therefore, the Electromobility Act has introduced a number of incentives for drivers who decide to buy electric cars, e.g. lower excise duty for electric vehicles and favourable 
depreciation rate, possibility of using restricted lanes by electric cars, as well as free parking in pay parking zones. Despite growing popularity and incentives, the share of electric vehicles on the market remains limited.

Some of the major barriers include the shortage of charging infrastructure, higher purchase cost comparing to combustion engine cars, time needed to recharge batteries and their capacity expressed as the distance to be covered per single charging. Thus, it is necessary to make travelling by car as friendly as possible for citizens and the environment. In this context, carsharing may be a solution. Carsharing is a short-term rental of cars in cities with special car rental businesses. In the largest Polish cities, private car rental systems are already in operation. The goal, however, should be to develop an urban carsharing system comprising a fleet of electric vehicles. The first attempt was made by Kraków (2018) and Wrocław (Transport-publiczny, 2018) which plan to launch electric carsharing as a part of their sustainable urban transport.

It seems that electric buses combined with electric cars, promoted inter alia through carsharing, can be a welcomed response to the needs of citizens. If so, it should improve the traffic flow in cities and air quality. At the same time, they may stimulate the growth of the electric car market in Poland.

\section{Stages of electromobility development and opportunities for Poland}

The development of advanced road and technical infrastructure will require Poland to make significant spending on building and maintenance of roads and technical facilities. Therefore, it is not possible to implement all feasible solutions overnight. Three stages of the process can be distinguished (Electromobility Development Plan in Poland. Energy for the Future, 2017):

- Stage I The first stage began in 2016 and should end by the end of 2018. It involves a number of pilot programmes designed to build public awareness. During the stage, the first prototypes of domestic electric cars and charging stations should be developed. Additionally, regulations should be drafted to provide for the market oriented legal framework.

- Stage II It is a post-pilot stage aimed at determining technical issues, such as the location of charging stations all over the country, the actual development of the power supply infrastructure to support electric and natural gas cars and the small series EV production. During that stage, technological solutions should be ready for larger EVs capable of transporting a larger number of passengers. This stage should end in 2020.

- Stage III It is the final stage which ends in 2025. Its purpose is to support public awareness regarding electromobility as an indispensable component of the rapidly changing environment in large cities. At that stage, the grid infrastructure should be able to cater for the power demand created by about one million electric vehicles. Moreover, local governments should have an ecological fleet and infrastructure accessible for citizens. This should additionally boost the interest in electromobility. We also expect an increased production of 
components by Polish companies and the first electric cars with full Polish content will be produced.

Being a new sector of industry and economy, electromobility may prove to be one of the key energy transformation factors. Over the years, electromobility can provide opportunity to stimulate the entire domestic industry. Therefore, there is a need to promote cooperation between companies which previously have not had a chance to cooperate. This may produce only positive results. Electromobility is closely linked with the application of modern technologies. Thus, it is necessary to analyse knowledge and innovation based measures, which involves solutions to be developed by research institutions and universities. One of the additional arguments supporting electromobility is that it benefits electric car buyers, such as price subsidies, tax incentives and exemptions (e.g. free parking and registration). Yet another advantage is that electric vehicles could use restricted lanes in cities and have special parking spots for EVs only.

The development of the power sector necessitates wider use of renewable energy sources, which in this particular case may be truly revolutionised. This is particularly true regarding micro and small installations designated for private use. Apart from required infrastructure, wind farms, especially offshore farms should be developed and used.

\section{Conclusions}

Electromobility is a new and increasingly important branch of the automotive industry. We have witnessed the development of new services and product related to that market segment. The growth of electromobility necessitates long-term major spending, especially in the initial period. After some time we will certainly notice a significant decrease in investment required and maintenance cost related to the infrastructure. Such costs will virtually stabilise. A difficulty might be the development of the legal framework to regulate the operation of electromobility in Poland. Such regulations should be favourable for users and encourage them to use EVs. The accessibility of charging stations will be needed and, at the same time, the service should be provided free of charge. We need to guarantee incentives, including subsidies, to encourage domestic and foreign investors to invest in manufacturing of electric vehicles and their components in Poland.

Together with the development of the energy sector, we need to continue the development of renewable energy sources. Moreover, attempts to reduce the number of vehicles in city centres and gradual retrofitting combustion engines with electric ones are supported by the care of the natural environment and human health.

\section{References}

ABB. (2018). Lidl powiększa swojq sieć stacji szybkiego ładowania pojazdów elektrycznych w Polsce o kolejne urzqdzenia $A B B$ [Lidl to increase its fast-charging network for electric cars in Poland with 
$\begin{array}{lllll}\text { further equipment by } & A B B] \text { from }\end{array}$ http://www.abb.pl/cawp/seitp202/f06651aa9ed45a66c12581370025c93a.aspx [in Polish].

Benveniste, G., Rallo, H., Canals Casals, L., Merino, A., \& Amante, B. (2018, November 15). Comparison of the state of Lithium-Sulphur and lithium-ion batteries applied to electromobility. Journal of Environmental Management, 226, 1-12. https://doi.org/10.1016/i.jenvman.2018.08.008

De Lara, F. F., \& Marx, R. (2018, June). Comparative positioning between Brazilian subsidiaries and European matrices on Electromobility and carsharing technologies. Research in Transportation Business \& Management, 27, 67-74. https://doi.org/10.1016/j.rtbm.2018.08.001

Drożdż, W. (2018). Elektromobilność w rozwoju miast [Electromobility in urban development]. Warsaw: Wydawnictwo Naukowe PWN [in Polish].

Drożdż, W. (2018). Operator systemu dystrybucji w dobie wyzwań innowacyjnej energetyki [Distribution System Operator and challenges for the innovative energy sector]. Zeszyty Naukowe Instytutu Gospodarki Surowcami Mineralnymi i Energiq Polskiej Akademii Nauk - The Bulletin of The Mineral and Energy Economy Research Institute of the Polish Academy of Sciences, 102. Retrieved from https://min-pan.krakow.pl/wydawnictwo/wp-content/uploads/sites/4/2018/03/20-zn-19drozdz.pdf [in Polish].

Electromobility Development Plan in Poland. 'Energy for the Future.' (2017). Warsaw: Ministry of Energy. Retrieved from https://www.gov.pl/attachment/e4658a6d-6fd5-4fb3-a3d3-325446ba9029

Electromobility and Alternative Fuel Act of $11^{\text {th }}$ January 2018, JoL item 317 (2018). Retrieved from http://prawo.sejm.gov.pl/isap.nsf/download.xsp/WDU20180000317/T/D20180317L.pdf [in Polish].

Kraków. (2018). Car-sharing w Krakowie coraz bliżej [Car-sharing in Kraków is approaching]. Retrieved from http://krakow.pl/aktualnosci/202867,29,komunikat,car-sharing_w_krakowie_coraz_blizej.ht $\mathrm{ml}$ [in Polish].

Lakhno, V., Malyukov, V., Bochulia, T., Hipters, Z., Kwilinski, A., \& Tomashevska, O. (2018). Model of managing of the procedure of mutual financial investing in information technologies and smart city systems. International Journal of Civil Engineering and Technology, 9(8), 1802-1812. Retrieved from http://www.iaeme.com/MasterAdmin/UploadFolder/IJCIET_09_08_181/IJCIET_ 09_08_181.pdf

May, N. (2018, October). Local environmental impact assessment as decision support for the introduction of electromobility in urban public transport systems. Transportation Research Part D: Transport and Environment, 64, 192-203. https://doi.org/10.1016/j.trd.2017.07.010

Merkisz, J. (2005). Przemysł silnikowy w Polsce [Engine manufacturing industry in Poland]. Silniki spalinowe - Combustion Engines, 3/2005(122), 12-21. Retrieved from http://www.combustionengines.eu/entityfiles/files/articles published/Ptnss-2005-03-02.pdf [in Polish].

MPiT. (2018). Program E-bus: Polski Autobus Elektryczny [E-bus Programme: Polish Electric Bus]. Retrieved from http://www.mpit.gov.pl/ebus [in Polish].

Onet. (2017). Solaris z tytułem Autobus roku 2017 za Urbino 12 electric [Solaris to receive the title of the Bus of 2017 for Urbino 12 electric]. Retrieved from http://biznes.onet.pl/wiadomosci/ transport/autobus-roku-2017-dla-solaris-urbino-12-electric/hxry77 [in Polish]. 
ORPA - Obserwatorium Rynku Paliw Alternatywnych [ORPA - Alternative Fuel Market Observatory]. (2018). Ewidencja infrastruktury paliw alternatywnych [Alternative Fuel Infrastructure Register] Retrieved from http://www.orpa.pl/infrastruktura/ [in Polish].

Polityka insight. (2018). Cicha rewolucja w energetyce Elektromobilność w Polsce [Quiet revolution in the energy sector. Electromobility in Poland]. Retrieved from https://www.politykainsight.pl/ resource/multimedium/20106685 [in Polish].

Portal Samorządowy [Local Government Portal]. (2018). Autobusy elektryczne: Polska liderem, ale wciq̨ż wiele do zrobienia [Electric Buses: Poland is a leader, but still much needs to be done. Retrieved from https://www.portalsamorzadowy.pl/gospodarka-komunalna/autobusy-elektryczne-polskaliderem-ale-wciaz-wiele-do-zrobienia,106167.html [in Polish].

Samochody elektryczne [Electric cars]. (2018). Wyniki sprzedaży samochodów EV/PHEV na świecie w $2017 \mathrm{r}$. [Sales of EV/PHEVs in the world in 2017]. Retrieved from http://samochodyelektryczne.org/wyniki sprzedazy samochodow ev phev na swiecie w 2017r. $\underline{\text { htm }}$ [in Polish].

Smoglab. (2018). Jakość powietrza w Polsce na tle Unii Europejskiej [Air quality in Poland 0-comparison with the European Union]. Retrieved from https://smoglab.pl/iakosc-powietrza-w-polsce-na-tleunii-europejskiej [in Polish].

Transport publiczny. (2018). Wrocław. Firma Enigma zbuduje car-sharing. Niedługo umowa (Enigma to develop car-sharing. Contract to be signed soon). Retrieved from http://www.transportpubliczny.pl/wiadomosci/wroclaw-firma-enigma-zbuduje-carsharing-niedlugo-umowa-54162.html [in Polish].

Wysokie napięcie. (2018). Stacje ładowania aut na prad: ile to kosztuje? [Charging stations for electric cars: how much does is cost?]. Retrieved from https://wysokienapiecie.pl/2457-stacje-ladowaniasamochodow-na-prad-ile-to-kosztuje-samochod-baterie-elektromobilnosc/[in Polish]. 